Могілевкіна I.O. ${ }^{1}$, Дорохіна А.M. ${ }^{2}$, Сіромаха C.O. $^{1,3}$

\title{
Впровадження австралійських класифікаторів для кодування пролікованих у стаціонарі випадків в Украӥні: перший досвід
}

\author{
${ }^{1}$ Національний медичний університет ім. О.О. Богомольця, м. Київ, Україна \\ ${ }^{2}$ ДУ «Національний науковий центр «Інститут кардіології ім. акад. М.Д. Стражеска» НАМН України, м. Київ, Україна \\ ${ }^{3}$ ДУ «Національний інститут серцево-судинної хірургії ім. М.М. Амосова НАМН України», м. Київ, Україна
}

imogilevkina@gmail.com, annadoroxina@ukr.net,newsersir@gmail.com

\author{
Могилевкина И.А., Дорохина А.Н., Сиромаха С.О. \\ Внедрение австралийских классификаторов \\ для кодирования пролеченных в стационаре случаев \\ в Украине: первый опыт
}

Mogilevkina I.O., Dorokhina A.M., Siromakha S.O. Implementation of Australian Classifiers for inpatient coding in Ukraine: first experience

\section{Встуі}

3 першого квітня 2020 року в Україні стартувала програма медичних гарантій, яка передбачає зміну оплати діяльності стаціонарів залежно від кількості та спектру складності пролікованих випадків. Впровадження оплати за випадки напряму має бути прив'язане до кодування випадків в стаціонарі, яке 321 грудня 2019 року має проводитись відповідно до наказу Мінекономіки від 13.12.2019 p. №677 «Про затвердження національних класифікаторів» [1]. Наказ затверджує використання в Україні НК 025:2019 - Класифікатора хвороб та споріднених проблем охорони здоров'я [2] та НК 026: 2019 - Класифікатора медичних інтервенцій [3]. Зазначені класифікатори можна знайти на сайті Міністерства охорони здоров'я (https://moz.gov.ua/dokumenti).

У передмові до класифікаторів написано, що національний класифікатор НК 025:2019 гармонізовано 3 Міжнародним статистичним класифікатором хвороб та споріднених проблем охорони здоров'я Десятого перегляду, Австралійської модифікації, 2017 (Тhe International Statistical Classification of Diseases and Related Health Problems, Tenth Revision, Australian Modification, ICD-10-AM, 2017), а національний класифікатор НК 026:2019 - 3 Австралійським класифікатором медичних інтервенцій (АКМI), 2017 (Australian Classification of Health Interventions, ACHI, 2017). Тобто, Україна прийняла для впровадження Міжнародний статистичний класифікатор хвороб та споріднених проблем охорони здоров'я Десятого перегляду, Австралійську модифікацію (МК-10-АМ, 2017) [4], так саме як і Австралійський класифікатор медичних інтервенцій (АКМІ, 2017) [5] замість існуючих в країні Міжнародної статистичної класифікації хвороб та споріднених проблем охорони здоров'я: Десятий перегляд: МКХ-10 [6] та Тимчасового галузевого класифікатору медичних процедур (послуг) та хірургічних операцій [7].
Пілотування запропонованих класифікаторів розпочалось в Україні з липня 2019 року після тренінгів 3 базового кодування (3-денний тренінг) [8], проведених міжнародним об'єднанням Карол Консалтін д.о.о. та Хелс Полісі Аналізіз у пілотних лікарнях в межах проекту «Пілотне впровадження системи ДСГ (на основі австралійської системи ДСГ) на рівні МО3 та вибраних медичних закладів (навчання, програмне забезпечення тощо)» (спільний зі Світовим Банком проект МОЗ України «Поліпшення охорони здоров'я на службі у людей»), шляхом внесення інформації щодо випадків, пролікованих в стаціонарах, до електронної системи Українських діагностично-споріднених груп (УДСГ) (https://udrgsystem.com), затвердженого постановою Кабінету Міністрів України від 25 березня 2015 року № 267, Плану заходів із впровадження системи діагностичноспоріднених груп в Україні, затвердженого наказом МO3 України від 29 серпня 2014 року № 605 та наказу МО3 № 2281 від 07.12.2018 "Про внесення змін до Переліку пілотних закладів охорони здоров'я для впровадження системи діагностично-споріднених груп".

Мета дослідження: покращити статистичну звітність закладів охорони здоровя II та III рівнів надання медичної допомоги, провівши аналіз відмінностей Міжнародного статистичного класифікатора хвороб та споріднених проблем охорони здоров'я Десятого перегляду, Австралійської модифікації та НК 025:2019 Класифікатора хвороб та споріднених проблем охорони здоров'я від МКХ-10, 1998, ВООЗ, з яким лікарі в Україні працювали протягом останніх років, визначити помилки при групуванні випадків в системі Українських діагностично-споріднених груп 3 якими стикнулися фахівці при кодуванні пролікованих в стаціонарі випадків при використанні МКХ-10-AM в пілотних лікарнях України та розробити кроки щодо усунення найчастіших помилок. 


\section{Матеріали та методи}

Обговорення відмінностей новітньог класифікатора: НК 025:2019 - Класифікатор хвороб та споріднених проблем охорони здоров'я, Міжнародного статистичного класифікатора хвороб та споріднених проблем охорони здоров'я Десятого перегляду, Австралійська модифікація, 2017 та Міжнародної статистичної класифікації хвороб та споріднених проблем охорони здоров'я: Десятий перегляд: МКХ-10 ВООЗ, 1998.

77603 випадки стаціонарного лікування, що внесені в електронну систему Українських діагностичноспоріднених груп (УДСГ) протягом липня-листопада 2019 року в 14 пілотних лікарнях України в межах Проекту, в яких автори публікації здійснювали моніторингові візити згідно плану проекту в грудні 2019 року. Дані щодо кодування збирались в системі УДСГ по кожній із пілотних лікарень після надання ними своїх кодів доступу із дотриманням правил захисту персональної інформації та етичних принципів при проведенні дослідження. В публікації представлені сирі дані без статистичної обробки.

\section{Результати дослідження та їх обговорення}

Впровадження новітніх класифікаторів ставить перш за все питання щодо їх відмінності від класифікаторів, які застосовувались у країні раніше.
Перш за все треба сказати, що при розробці МКХ10-АМ не вносилось жодних змін до структури МКХ-10 BOO3, значення кодів тризначних та чотиризначних рубрик залишені незмінними, однак додано відповідні роз'яснення в деяких місцях, усі зміни відповідали існуючим кодам та конвенціям МКХ-10 ВООЗ та збережено можливість порівнювати дані за різний час [9]. МКХ-10-АМ сумісна зі своєю материнською системою (МКХ-10 ВОО3) і повністю задовольняє можливу потребу у порівнянні статистичних даних щодо захворюваності та смертності на міжнародному рівні. Тобто, цей документ не $\epsilon$ новим для фахівців, тому що протягом багатьох років вони користувалися МКХ-10 ВООЗ.

Проте, МКХ-10-АМ містить низку тризначних рубрик, з яких виключено подальші підрубрики, в ній додано низку нових рубрик та підрубрик, 3 метою забезпечення більш коректного кодування деяких станів додано відповідні додаткові детальні роз'яснення та примітки. Передбачений МКХ-10-АМ підхід дозволяє забезпечити клінічне кодування, яке максимально відповідає наявним у кожного конкретного пацієнта хворобам чи іншим пов'язаним із здоров'ям станам (діагнозам).

Прикладом виключення подальших підрубрик 3 тризначних рубрик $є$ розділ В20-В24 - Хвороби, зумовлені вірусом імунодефіциту людини (ВІЛ). В МКХ-10-АМ на відміну від МКХ-10 (ВООЗ) залишені тільки тризначні рубрики, з яких виключено підрубрики (таблиця 1).

\section{Таблиця 1. Приклад виключення чотиризначних рубрик з МКХ-10-АМ}

\section{МКX-10-AM (4)}

В20 Хвороба, зумовлена вірусом імунодефіциту людини [ВІЛ], яка проявляється інфекційними та паразитарними хворобами

Xво

\section{МКХ-10 (ВОО3) (6)}

В20 Хвороба, зумовлена вірусом імунодефіциту людини [ВIЛ], яка проявляється інфекційними та паразитарними хворобами

В20.0 Хвороба, зумовлена ВІЛ з проявами мікобактеріальної інфекції В20.1 Хвороба, зумовлена ВІЛ з проявами інших бактеріальних інфекцій В20.2 Хвороба, зумовлена ВІЛ з проявами цитомегаловірусної хвороби В20.3 Хвороба, зумовлена ВІЛ з проявами інших вірусних інфекцій В20.4 Хвороба, зумовлена ВІЛ з проявами кандидозу

В20.5 Хвороба, зумовлена ВІЛ з проявами інших мікозів В20.6 Хвороба, зумовлена ВІЛ з проявами пневмонії визваної Pneumocystis carinii В20.7 Хвороба, зумовлена ВІЛ з проявами множинних інфекцій В20.8 Хвороба, зумовлена ВІЛ з проявами інших інфекційних чи паразитарних Хвороб

В20.9 Хвороба, зумовлена ВІЛ з проявами неуточненої інфекційної чи паразитарної хвороби
Якщо у пацієнта розвиваються прояв, що вказує на розвиток асоційованої з ВІЛ хвороби, госпіталізація такого пацієнта кодується кодами з рубрик В20-В24 [10]. Виключення підрубрик дозволяє розмежувати випадки, коли причиною госпіталізації був саме ВІЛ або його прояв. Якщо основною причиною госпіталізації для надання пацієнту допомоги був ВІЛ, слід використовувати коди 3 рубрик В20-В24. Якщо основною причиною госпіталізації був прояв ВІЛ, в якості основного діагнозу має кодуватись прояв ВІЛ.

Наприклад, в разі госпіталізації для лікування кандидозу ротової порожнини у хворого з ВІЛ, згідно 3 МКХ-10-АМ маємо кодувати: В37.0 - Кандидозний стоматит та В20 - Хвороба, зумовлена вірусом імунодефіциту людини (ВІЛ), яка проявляється інфекційними та паразитарними хворобами [10], тоді як 
раніше в МКХ-10 (ВОО3) встановлювався один код В20.4 Хвороба, зумовлена ВІЛ з проявами кандидозу. Тобто австралійських підхід дозволяє чітко розмежувати, що саме було причиною госпіталізації. Але таке кодування потребує змін в нормативних документах MO3, особливо у випадках скерування пацієнта на медико-соціальну експертну комісію (МСЕК) для встановлення інвалідності, коли ВІЛ, за рахунок зміни класифікатора, виноситься не в якості основного, а в якості додаткового (супутнього!) діагнозу.

Інший приклад виключення подальших підрубрик розділ «Характер розродження» - О80-О84. В МКХ-10 (BOO3) код О80 передбачає розподіл на декілька підрубрик (див. таблицю 2).
MКХ-10-АМ виключає подальші підрубрики тризначних кодів за рахунок виключення інформації щодо передлежання плода при самовільному розродженні. Ця інформація перенесена в класифікатор інтервенцій, тому що втручання або інтервенції, при різному передлежанні відрізняються. Тобто, в МКХ-10-АМ матимемо тільки тризначні коди, щодо характеру розродження, але при кодуванні до останніх обов'язково повинні додаватися коди АКМІ, тобто коди, які описують надану допомогу.

Проте, клінічний досвід свідчить, що в багатьох випадках кодування повинно дозволяти більшу деталізацію стану пацієнта. Прикладом такої ситуації $є$ поява п'ятого знаку в кодах МКХ-10-АМ порівняно 3 кодами МКХ-10 (ВОО3) (табл. 3).

\section{Таблиця 2. Кодування характеру розродження в МКХ-10-АМ та МКХ-10, ВООЗ}

\begin{tabular}{|l|l|}
\hline \multicolumn{1}{|c|}{ МКХ-10-АМ (4) } & \multicolumn{1}{c|}{ АКМІ (5) } \\
\hline $\begin{array}{l}\text { О80 Пологи одноплідні, } \\
\text { спонтанне розродження }\end{array}$ & $\begin{array}{l}\text { 90467-00 [1336] Самовільне } \\
\text { розродження при тім'яному } \\
\text { передлежанні плода }\end{array}$ \\
& $\begin{array}{l}\text { 90470-00 [1339] Самовільне } \\
\text { розродження при сідничному } \\
\text { передлежанні плоду }\end{array}$ \\
&
\end{tabular}

\section{MKX-10 (BOO3) (6)}

О80 Пологи одноплідні, самовільне розродження

О80.0 Самовільне розродження при тім'яній передлозі плода

О80.1 Самовільне розродження при сідничній передлозі плода

О80.8 Інші одноплідні пологи з самовільним розродженням

О80.9 Одноплідні пологи з самовільним розродженням, неуточнені

\section{Таблиця 3. Додавання п'ятизначних рубрик в МКХ-10-АМ}

\section{MKX-10 (BOO3) (6)}

В95.4 Інші стрептококи, які є причиною захворювань, класифікованих в інших рубриках

\section{Р37.5 Неонатальний кандидоз}

Тобто, додатковий п'ятий знак дозволяє точніше та детальніше описати стан пацієнта, який потребує госпіталізації та стаціонарного лікування.

Цікавий приклад нового для нас чотиризначного коду в МКХ-10-АМ - розділ Р91 - Інші розлади церебрального статусу у новонародженого (табл. 4).
В95.4 Інші стрептококи як причина хвороб, класифікованих в інших рубриках

В95.41 Стрептококи групи С як причина хвороб,
класифікованих в інших рубриках
В95.42 Стрептококи групи G як причина хвороб,
класифікованих в інших рубриках
В95.48 Стрептококи іншої уточненої групи як причина хвороб,
класифікованих в інших рубриках
Р37.5 Кандидоз новонародженого
P37.50 Кандидоз новонародженого, неуточнений
Р37.51 Топічний або шлунково-кишковий кандидоз
новонародженого. Кандидоз новонародженого, що вражає:
- шкіру та слизові оболонки
- ротової порожнини
- перинеальний
Р37.52 Інвазивний кандидоз новонародженого.
Генералізований кандидозний сепсис новонародженого
Р37.59 Інший кандидоз новонародженого
класифікованих в інших рубриках класифікованих в інших рубриках В95.48 Стрептококи іншої уточненої групи як причина хвороб, класифікованих в інших рубриках

Р37.50 Кандидоз новонародженого, неуточнений P37.51 Топічний або шлунково-кишковий кандидоз - шкіру та слизові оболонки Ренералізований кандидозний сепсис ново
Вражаючим $\epsilon$ те, що чотиризначна рубрика P91.6 Гіпоксично-ішемічна енцефалопатія [ГIE] у новонародженого існує в МКХ-10 (ВОО3) з 2006 року. На жаль, ця рубрика була відсутня в українській версії MKX-10, яка базувалась на MKX-10, 1998 року і якою ми користувалися до сьогодні. Протягом більше ніж 20 років 
в Україні класифікатор не оновлювався. Тому, скоріше за все, практично всі нові для нас чотиризначні рубрики - не щось нове додане австралійцями, а те, що було внесено ВОO3 до класифікатора протягом багатьох років, те, що ми не враховували через використання застарілої версії класифікатора 1998 року.

Таким чином, МКХ-10-AМ не $\epsilon$ чимось новим, 3 чим ми не зустрічалися. Вона грунтується на МКХ-10, ВOO3, тобто на класифікації з якою ми добре знайомі, і яка використовувалась протягом багатьох років.

Протягом липня-листопада 2019 року чотирнадцять пілотних лікарень, ввели в систему Українських ДСГ (UDRG) 77603 випадки стаціонарного лікування. 3 них віднесено до різних діагностично-споріднених груп (ДСГ) 67049 випадків, тобто, 86,4\% випадків. Це означає, що якби оплата за пролікований випадок впроваджувалась сьогодні, то лікарні отримали б гроші лише за $86,4 \%$ виписаних пацієнтів. 13,6\% випадків це невірно закодовані випадки, які мали б бути уточнені, перш ніж за них могли б надійти кошти.

Некласифіковані (невіднесені до тієї чи іншої діагностично-спорідненої групи) випадки із основними причинами допущених при клінічному кодуванні помилок наведені в таблиці 5 .

Структура помилок некласифікованих до ДСГ випадків представлена на рисунку 1.

\section{Таблиця 4. Доповнення чотиризначних (?) та п'ятизначних рубрик в МКХ-10-АМ (4)}

\section{Р91 Інші розлади церебрального статусу у новонародженого}

Р91.0 Ішемія мозку у новонародженого

Р91.1 Набуті перивентрикулярні кісти у новонародженого

Р91.2 Церебральна лейкомаляція у новонародженого

Р91.3 Церебральна збудливість у новонародженого

Р91.4 Церебральна депресія у новонародженого

Р91.5 Неонатальна кома

P91.6 Гіпоксично-ішемічна енцефалопатія [ГІЕ] у новонародженого

Необхідно також кодувати супутню тяжку асфіксію при народженні

P91.60 Гіпоксично-ішемічна енцефалопатія [ГIE] у новонародженого, неуточнена

P91.61 Гіпоксично-ішемічна енцефалопатія [ГIЕ] у новонародженого 1 стадії Стадія 1. Легка: гіпоксично-ішемічна енцефалопатія [ГIE] у новонародженого

P91.62 Гіпоксично-ішемічна енцефалопатія [ГIE] у новонародженого 2 стадії Стадія 2. Помірна: гіпоксично-ішемічна енцефалопатія [ГIE] у новонародженого Включено: судоми

P91.63 Гіпоксично-ішемічна енцефалопатія [ГIE] у новонародженого 3 стадії Стадія 3. Важка: гіпоксично-ішемічна енцефалопатія [ГIE] у новонародженого Включено: судоми

Р91.7 Набута гідроцефалія у новонародженого

Р91.8 Інші уточнені розлади церебрального статусу у новонародженого

Р91.9 Розлад церебрального статусу у новонародженого, неуточнений

Таблиця 5. Помилки при групування випадків в системі Українських діагностично-споріднених груп (UDRG - https://www.udrg-system.com) на прикладі 14 пілотних закладів охорони здоров'я за даними аналізу 77603 випадків

\begin{tabular}{|c|c|c|c|c|}
\hline $\begin{array}{c}\text { Код } \\
\text { помилки }\end{array}$ & Статус групування & Опис & $\begin{array}{l}\text { Кількість } \\
\text { випадків }\end{array}$ & $\%$ \\
\hline 02 & $\begin{array}{l}\text { Діагноз не може бути } \\
\text { використано як } \\
\text { основний діагноз }\end{array}$ & $\begin{array}{l}\text { 1. Код знаходиться в діапазоні U50-Y98, що } \\
\text { використовується в якості основного діагнозу } \\
\text { або } \\
\text { 2. Встановлений діагноз не може бути основним }\end{array}$ & 317 & 0,408 \\
\hline 03 & $\begin{array}{l}\text { Епізод не відповідає } \\
\text { критеріям жодної } \\
\text { ДСГ }\end{array}$ & $\begin{array}{l}\text { Основний діагноз не належить до жодної ДСГ або } \\
\text { епізод не може бути віднесено до ДСГ за допомогою } \\
\text { алгоритму }\end{array}$ & 9995 & 12,88 \\
\hline 04 & Неприпустимий вік & Вік не можна отримати у допустимому діапазоні & 2 & 0,003 \\
\hline 05 & Неприпустима стать & $\begin{array}{l}\text { Недопустима стать або конфлікт даних про стать } 3 \\
\text { основним діагнозом }\end{array}$ & 30 & 0,039 \\
\hline 07 & $\begin{array}{l}\text { Неприпустима вага } \\
\text { при госпіталізації }\end{array}$ & $\begin{array}{l}\text { Якщо вік пацієнта введено або розраховано як } 364 / 365 \\
\text { днів або менше, значення ваги при госпіталізації є } \\
\text { недопустимим і основний діагноз є діагнозом } \\
\text { новонародженого }\end{array}$ & 210 & 0,271 \\
\hline \multicolumn{3}{|c|}{ Всього випадків: } & 10554 & 13,6 \\
\hline
\end{tabular}




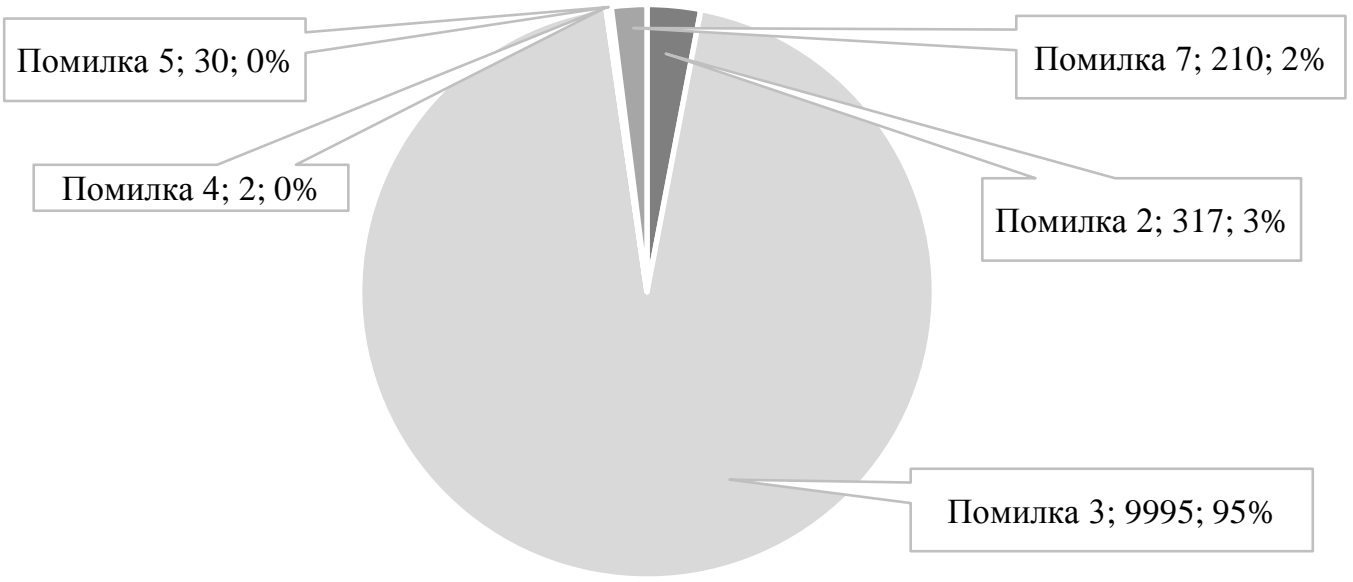

Рис. 1. Структура помилок при внесенні даних в систему UDRG

Середня кількість додаткових діагнозів на одного пацієнта в пілотних лікарнях складала 1,68 (коливаючись від 0,5 до 4,6). Середня кількість інтервенцій (втручань) на одного пацієнта складала 4,9, коливаючись від 1 до 9,4.

Серед некласифікованих в ДСГ випадків найчастіше зустрічалась помилка 03, тобто «Епізод не відповідає критеріям жодної ДСГ». Така помилка зазвичай пов'язана із некоректним обранням коду основного діагнозу з МКХ-10-АМ або його невідповідності виконаній інтервенції. Більш того, у бататьох випадках інтервенції кодувались лише частково, наприклад, кодувалась операція та не кодувалась анестезія.

Тому в даній публікації ми вирішили представити додаткові алгоритми, щодо пошуку необхідних кодів в MKX-10-AM.

\section{Пошук кодів в МКХ-10-АМ}

Важливо відзначити, що, хоча МКХ і призначена для класифікації, перш за все, хвороб та травм, що мають чітко сформульований діагноз, не кожну проблему або причину звернення за медичними послугами можна класифікувати таким чином. Відповідно, МКХ передбачає можливість широкого розмаїття ознак, симптомів, відхилень, виявлених в процесі дослідження, скарг та соціальних обставин, які можуть бути вписані на місці діагнозу в медичній документації (4).

Так саме, як в МКХ-10 ВООЗ, у рамках МКХ-10АМ застосовуються різні підходи до класифікації. Структуру системи орієнтовано, в першу чергу, на сприяння виконанню епідеміологічного аналізу. Хвороби поділено на такі групи: епідемічні хвороби; конституційні або системні захворювання; місцеві захворювання за місцем ураження; вади розвитку; травми. Перші дві й останні дві з цих груп - «спеціальні групи», що об’єднують захворювання, які були б розташовані незручно для епідеміологічного дослідження, якби вони були розкидані, приміром, в разі використання класифікації за місцем ураження. Залишається ще група «місцеві захворювання за місцем ураження», що містить класи МКХ-10-АМ для кожної з основних систем організму.
Після визначення основного поняття, що має бути закодованим, перший крок в пошуку необхідного коду це вирішення, в якому класі ми повинні шукати код відповідного діагнозу або стану (рисунок 2).

Класи розбиваються на однорідні блоки з рубрик, закодованих трьома знаками. Діапазон рубрик наводиться в дужках після назви кожного блоку (рисунок 3 ).

У кожному блоці тризначні рубрики поєднують групи хвороб з певними спільними характеристиками. Деякі тризначні рубрики призначені для одиночних хвороб, що вирізняються частотою випадків, складністю або чутливістю до інтервенцій в рамках системи охорони здоров'я. Зазвичай передбачені також рубрики для «інших» станів, куди можна включати багато різних, але менш розповсюджених захворювань, а також «невизначені» стани.

Другий крок - пошук необхідної рубрики. Для пошуку необхідної тризначної рубрики треба зайти в потрібний клас, далі, переглядаючи перелік тризначних рубрик, знайти ту, де за вашою думкою може знаходитись потрібний код стану/хвороби.

Третій крок - пошук необхідного коду. Для цього в електронній версії табличного переліку хвороб МКХ-10AM треба набрати тризначний номер блоку, перейти до сторінки, 3 тризначним кодом блоку на фоні чорного кольору, або з кодом блоку виділеним чорною рамкою (рисунок 4).

Текст, виділений чорним кольором, позначає тризначні коди, які не $є$ дійсними та не можуть бути присвоєні, оскільки такі коди вимагають додаткової деталізації (рисунок 5). Текст, виділений сірим кольором, позначає чотиризначні коди, які також не $є$ дійсними та не можуть бути присвоєні, оскільки такі коди також вимагають додатковий знак. Текст, виділений рамкою, використовується для позначення тризначних кодів, які $\epsilon$ дійсними (4). Червоний трикутник $\boldsymbol{\nabla}$ - цей символ того, що до певного коду або групи кодів (категорії або блоку) застосовуються Австралійські стандарти кодування (10) і необхідно ознайомитися зі стандартом перед присвоєнням коду (кодів). Відповідний номер стандарту зазначений біля символу. 


\begin{tabular}{|c|c|c|c|}
\hline Клас & Назва класу & $\begin{array}{l}\text { Префікс } \\
\text { коду }\end{array}$ & Тип групи \\
\hline Kлас 1 & Деякі інфекційні та паразитарні хвороби & A, B & Спеціальна \\
\hline Kлас 2 & Новоутворення & C, D & Спеціальна \\
\hline Клас 3 & $\begin{array}{l}\text { Хвороби крові та кровотворних органів, та окремі порушення з залученням імунного } \\
\text { механізму }\end{array}$ & D & За місцем \\
\hline Клас 4 & Хвороби ендокринної системи, розлади харчування та порушення обміну речовин & $\mathrm{E}$ & За місцем \\
\hline Клас 5 & Розлади психіки та поведінки & $\mathrm{F}$ & За місцем \\
\hline Krac 6 & Хвороби нервової системи & G & Ва місцем \\
\hline Krac 7 & Хвороби ока та придаткового апарату & $\mathrm{H}$ & За місцем \\
\hline Kлас 8 & Хвороби вуха та соскоподібного відростка & $\mathrm{H}$ & За місцем \\
\hline Kлас 9 & Хвороби системи кровообігу & I & За місцем \\
\hline Kлаa 10 & Хвороби органів дихання & $\mathrm{J}$ & За місцем \\
\hline Kлас 11 & Хвороби органів травлення & $\mathrm{K}$ & За місцем \\
\hline Kлlac 12 & Хвороби шкіри та підшкірної клітковини & $\mathrm{L}$ & За місцем \\
\hline Kлас 13 & Хвороби кістково-м'язової системи та сполучної тканини & M & За місцем \\
\hline Kлас 14 & Хвороби сечостатевої системи & $\mathrm{N}$ & За місцем \\
\hline Kлrac 15 & Вагітність, пологи та післяпологовий період & 0 & Спеціальна \\
\hline Kлас 16 & Окремі стани, що виникають у перинатальному періоді & $\mathrm{P}$ & Спеціальна \\
\hline Клас 17 & Природжені вади розвитку, деформації та хромосомні аномалії & Q & Спеціальна \\
\hline Клас 18 & $\begin{array}{l}\text { Симптоми, ознаки та відхилення від норми, виявлені при лабораторних та клінічних } \\
\text { дослідженнях, не класифіковані в інших рубриках }\end{array}$ & $\mathrm{R}$ & H/A \\
\hline Клас 19 & Травми, отруєння та деякі інші наслідки дії зовнішніх причин & $\mathrm{S}, \mathrm{T}_{\text {dows }}$ & Спеціальна \\
\hline Kлас 20 & Зовнішні причини захворюваності та смертності & $U, \mathrm{~V}, \mathrm{~W}, \mathrm{X}, \mathrm{Y}$ & $H / A$ \\
\hline Клас 21 & $\begin{array}{l}\text { Фактори, що впливають на стан здоров'я населення та звернення до закладів охорони } \\
\text { здоров'я }\end{array}$ & Z & H/A \\
\hline Kuac 22 & Коди для спеціальних цілей & $\mathrm{U}$ & H/Д \\
\hline
\end{tabular}

Рис. 2. Класи МКХ-10-АМ (4)

КЛАС 1 ДЕЯКІ ІНФЕКЦІЙНІ ТА ПАРАЗИТАРНІ ХВОРОБИ (А00-В99)

Кишкові інфекційні хвороби (А00-А09)

А00 Холера

А01 Черевний тиф та паратиф

А02 Інші сальмонельозні інфекції

А03 Шигельоз

А04 Інші бактеріальні кишкові інфекції

А05 Інші бактеріальні харчові отруєння, не класифіковані в інших рубриках

А06 Амебіаз

А07 Інші протозойні кишкові хвороби

А08 Вірусні та інші уточнені кишкові інфекції

A09 Інший гастроентерит та коліт інфекційного та неуточненого походження

Рис. 3. Тризначні рубрики (4)

110 Есенціальна (первшнна) гіпертензія

Високий кров'яний тиск

Гіпертонія (артеріальна) (доброякісна) (есенціальна) (злоякісна) (первінна) (сістемна)

Виключено: з залученням суднн

- головного мозку (I60 - I69)

- ока $(\mathrm{H} 35.0)$

I11

Гіпертензпвна (гіпертонічна) хвороба серця

Включено: будь-який стан, зазначеннй у рубрпкках I50.-, I51.4-151.9, обуумовлений гіпертонією

I11.0 Гіпертензивна (гіпертонічна) хвороба серця з (застійною) серцевою недостатністю Гіпертензивна (гіпертонічна) серцева недостатність

I1 1.9 Гіпертензивна (гіпертонічна) хвороба серця без (застійної) серцевої недостатності Гіпертензивна (гіпертонічна) хвороба серця БДВ

Рис. 4. Пошук коду стану в МКХ-10-АМ (4) 
Ао0 Холера

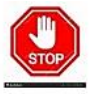

A41.5 Септицемія, спричинена іншими грамнегативними мікроорганізмами

А33 Правець новонародженого (КОДУєМО!)

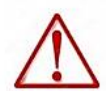

A41

Інший сепсис (ПРАВИЛА КОДУВАННЯ!)

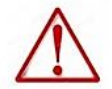

$\nabla 0110$

A49.01

Інфекція Staphylococcus aureus неуточненої

$\nabla 0111$ локалізації (ПРАВИЛА КОДУВАННЯ!)

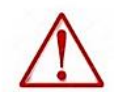

Рис. 5. Правила кодування

Таким чином, якщо маємо код на чорному або сірому фоні, необхідно шукати наступний чотиризначний, або п’ятизначний код з даної рубрики. Наявність хрестика або зірочки біля коду говорить про необхідність кодування двох станів, визначених як зірочкою, так і хрестиком. Обов'язково потрібно звертати увагу на включені та виключені поняття.

Тобто, кодуючи гастрит та дуоденіт не можна обрати код К29, або К29.2-К29.9 (рисунок 6). Маємо обрати або коди К29.0 чи К29.1, або один з п'ятизначних кодів, наприклад - К29.70. Коди на чорному та сірому фоні $\epsilon$ недійсними.

Тобто, алгоритм пошуку потрібного коду в МКХ10-АМ з прикладом, а саме кодування діагнозу можна представити наступним чином (рисунок 7).

Таким чином, застосування в межах пілотного проекту спрощеної системи Українських ДСГ, яка не дозволяє розібратися, які коди не є дійсним, де відсутня інформація щодо включених та виключених понять, відсутні позначки хрестик та зірочка та додаткові пояснення щодо кодування в багатьох випадках робить неможливим коректний вибір коду (рисунок 8).

3 нашої точки зору, саме підхід до кодування 3 використанням тільки системи Українських ДСГ $є$ відповідальним за майже 13\% помилок при групуванні випадків у системі УДСГ, коли основний діагноз не належить до жодної ДСГ або епізод не може бути віднесено до ДСГ за допомогою алгоритму. Тому, перш ніж вводити дані в систему, потрібно обрати коректні коди в табличному переліку класифікатора і тільки після цього вносити їх в систему.

Більш того, вигляд в якому нові класифікатори затверджені в Україні та представлені на сайті МO3, жодним чином не допоможе в кодуванні, оскільки в ньому, так саме як і в пілотній системі УДСГ відсутні важливі пояснення, включені та виключені поняття, анотації, пунктуації, важко зрозуміти який код є дійсним, а який ні (рисунок 9).

\section{к29 Гастрит і дуоденіт}

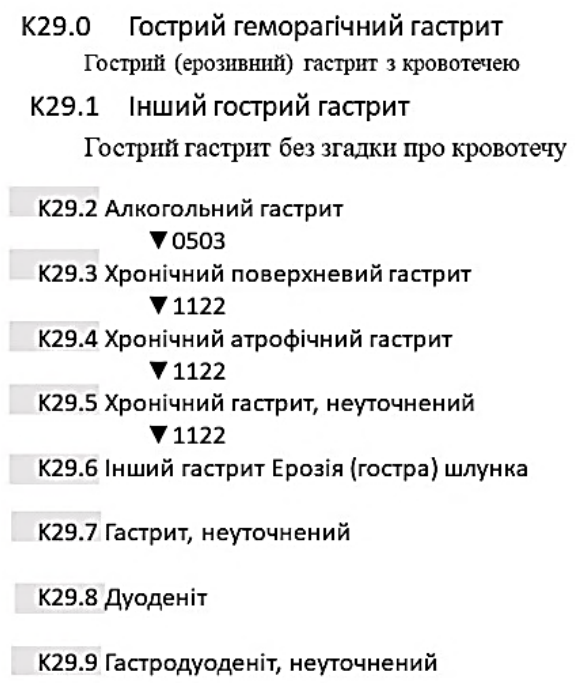

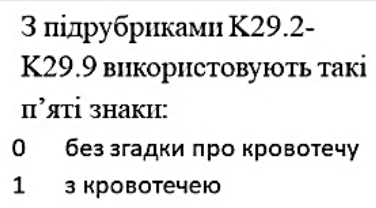

Рис. 6. Вибір коду стану (4) 
Пошук необхідного коду в MKX-10-AM Ч Чоловік госпіталізований для проведення процедури видалення пілонідальної кісти куприка

Визначте основне поняття

Клас?

ПЕРЕЛІК КЛАСІВ

Рубрика?

ПЕРЕЛІК ТРИЗНАЧНИХ РУБРИК

Діагноз?

ТАБЛИЧНИЙ ПЕРЕЛІК ХВОРОБ

Діагноз: МКX-10-АM
Основне поняття - пілонідальна кіста куприка

КЛас? - ПЕРЕЛІК КЛАСІВ

Клас 12. Хвороби шкіри та підшкірної клітковини

РУбрика? - ПЕРЕЛІК ТРИЗНАЧНИХ РУБРИК

Інфекційні хвороби шкіри та підшкірної клітковини (LOO-LO8)

L05 Пілонідальна кіста

ДіагНОЗ? - ТАБЛИЧНИЙ ПЕРЕЛІК ХВОРОБ

L05 Пілонідальна кіста

L05.9 Пілонідальна кіста без абсцесу

Діагно3: L05.9 Пілонідальна кіста без абсцесу

Рис. 7. Алгоритм пошуку коду в МКХ-10-АМ та приклад кодування

Основний діагно3 *

N40 - Гіперплазія передміхурової залози

Тип медичної допомоги

Години механічної вентиляції

Вага новонародженого [r]

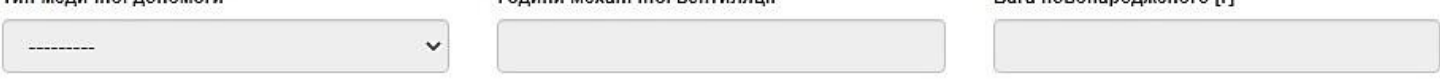

\begin{tabular}{l|l|l|l|l|l|l|}
\hline Дата виписки * & Режим виписки * \\
\hline $07-09-2019$ & Виписано додому/інше
\end{tabular}

Бал SAPS II при виписці 3 відділення інтенсивної допомоги

Переведено до медичного закладу

Додаткові діагнози

N21.0 - Камені в сечовому міхурі

R33 - Затримка сечі
125.2 - Перенесений у минулому інфа

|11.0 - Гіпертензивна (гіпертонічна) $\mathrm{x|}$

Рис. 8. Некоректні джерела для пошуку коду станів (основний та додаткові діагнози) система Українських ДСГ (UDRG) (8)

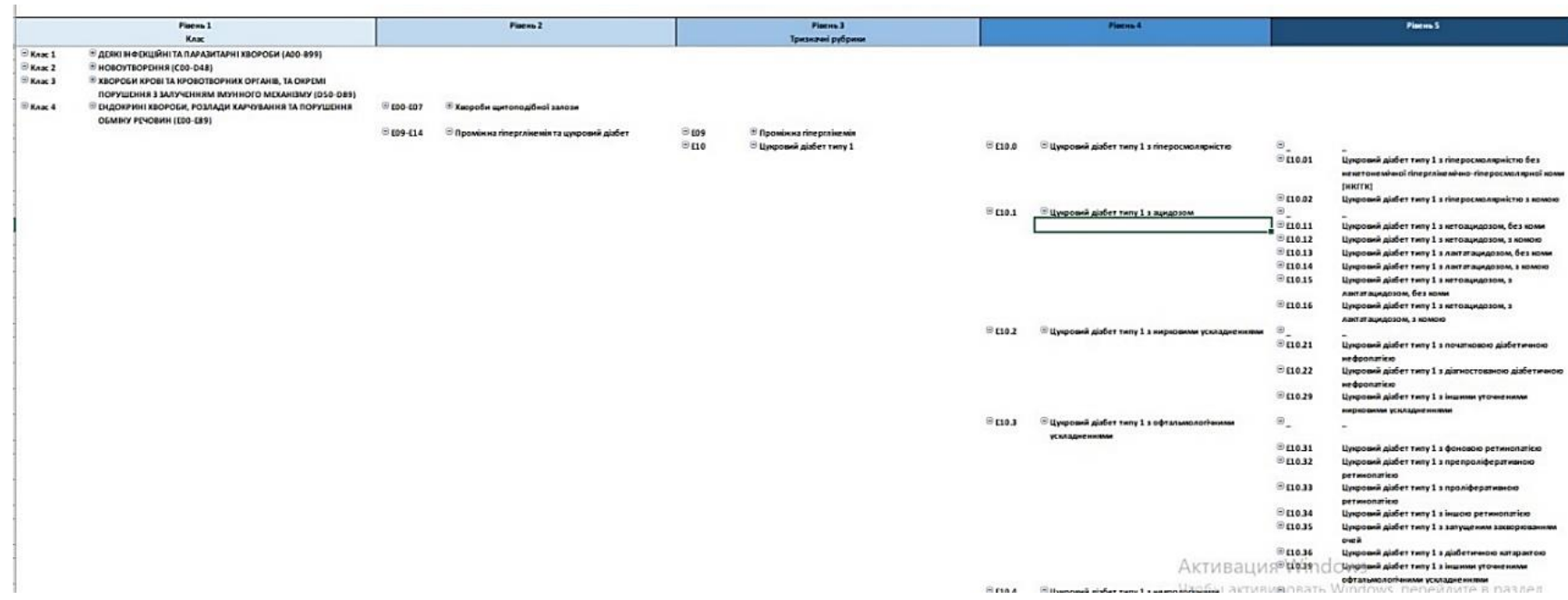

Рис. 9. Некоректні джерела для пошуку коду станів - НК 025:2019 -

Класифікатора хвороб та споріднених проблем охорони здоров'я, 2019 (2) 
Розробка алфавітного показчика хвороб та станів може частково вирішити цю проблему. Хоча, для ефективної роботи лікарі та статистики повинні мати повноцінний класифікатор МКХ-10-АМ: Табличний перелік, саме такий, який були розповсюджені в межах пілотного Проекту, та який на сьогодні опубліковано на сайті НСЗУ в межах тренінгів щодо кодування.

Важливим компонентом коректного кодування при використанні МКХ-10-АМ є австралійські стандарти кодування (10), що дають вичерпні пояснення щодо кодування як станів, так і втручань. Опис стандартів - це окреме, хоча і дуже важливе питання для розгляду, що знаходиться за межами даної публікації. На сьогодні цей документ ще не затверджений в Україні, хоча i опублікований на сайті НСЗУ. Між тим, тільки робота 3 ним дозволить привести кодування стаціонарних випадків до міжнародних стандартів, що $\epsilon$ запорукою коректного врахування витрат на надання допомоги при впровадженні оплати за пролікований випадок. Тобто, критично важливим для впровадження нових класифікаторів в Україні буде забезпечення медичних закладів та лікарів принаймні електронними версіями всіх трьох класифікаторів та проведення додаткових навчань щодо їх використання.

\section{Перспективи подальших досліджень}

Подальші дослідження можуть включати як вивчення різних технологій щодо впровадження кодування пролікованих випадків в стаціонарах, так і порівняння структури ДСГ в лікувальних закладах різного рівня.

\section{Висновки}

Проведене дослідження показало, що відмінності запропонованого класифікатора хвороб та споріднених проблем охорони здоров'я від того, що до сьогодні використовувся в Україні не є критичними та не будуть перешкодою у впровадженні класифікатора. Лише 13,6\% випадків були не віднесені до ДСГ, найчастіше за рахунок помилок з вибором коректного коду в МКХ-10-АМ. При впровадженні класифікатора в країні додатково треба зосередитись на алгоритмі пошуку необхідних кодів в MКХ-10-AМ. Не можна обмежуватись запропонованим в країні варіантом класифікатора НК 025:2019. Всі три перекладені класифікатори в повному обсязі мають бути доступними для фахівців, задіяних в процесі кодування.

\section{Література/References}

1. Наказ Мінекономіки від 13 грудня 2019 року №677 Про затвердження національних класифікаторів. (Nakaz Minekonomiky vid 13 hrudnia 2019 roku №677 Pro zatverdzhennia natsionalnykh klasyfikatoriv).

2. Класифікатор хвороб та споріднених проблем охорони здоров’я НК 025:2019, Київ, МОЗ України, 2019 р. (Klasyfikator khvorob ta sporidnenykh problem okhorony zdorovia NK 025:2019, Kyiv, MOZ Ukrainy, 2019 r.).

3. Класифікатор медичних інтервенцій НК 026:2019, Київ, МОЗ України, 2019 p. (Klasyfikator medychnykh interventsii NK 026:2019, Kyiv, MOZ Ukrainy, 2019 r.).

4. The International Statistical Classification of Diseases and Related Health Problems, Australian Modification (ICD10-AM). Tabular List, Tenth Revision, 1 July 2017. Independent Hospital Pricing Authority, 2017 (Міжнародна статистична класифікація хвороб та споріднених проблем охорони здоров’я. Десятий перегляд, Австралійська модифікація: Табличний перелік. Десяте видання 1 липня 2017 р. НУКЦПМУ Незалежне управління по контролю цінової політики медичних установ https://academy.nszu.gov.ua/) (Mizhnarodna statystychna klasyfikatsiia khvorob ta sporidnenykh problem okhorony zdorovia. Desiatyi perehliad, Avstraliiska modyfikatsiia: Tablychnyi perelik. Desiate vydannia 1 lypnia 2017 r. NUKTsPMU Nezalezhne upravlinnia po kontroliu tsinovoi polityky medychnykh ustanov https://academy.nszu.gov.ua/).

5. Australian Classification of Health Interventions. ACHI. Tabular List. Tenth Edition, 1 July 2017. Independent Hospital Pricing Authority, 2017 (Австралійський класифікатор медичних інтервенцій (АКМI): Табличний перелік інтервенцій. Десяте видання 1 липня 2017 р. НУКЦПМУ Незалежне управління по контролю цінової політики медичних установ https://academy.nszu.gov.ua/) (Avstraliiskyi klasyfikator medychnykh interventsii (AKMI): Tablychnyi perelik interventsii. Desiate vydannia 1 lypnia 2017 r. NUKTsPMU Nezalezhne upravlinnia po kontroliu tsinovoi polityky medychnykh ustanov https://academy.nszu.gov.ua/).

6. Міжнародна статистична класифікація хвороб та споріднених проблем охорони здоров'я: Десятий перегляд: МКХ-10 [Текст] : [Пер. з англ.] / ВООЗ, Укр. ін-т громад.здоров'я. - К. : Здоров'я, 1998. (Mizhnarodna statystychna klasyfikatsiia khvorob ta sporidnenykh problem okhorony zdorovia: Desiatyi perehliad: MKKh-10 [Tekst] : [Per. z anhl.] / VOOZ, Ukr. in-t hromad. zdorovia. - K. : Zdorovia, 1998).

7. Тимчасовий галузевий класифікатор медичних процедур (послуг) та хірургічних операцій, затверджений наказом МО3 України від 14.02.2007 p. № 67. (Tymchasovyi haluzevyi klasyfikator medychnykh protsedur (posluh) ta khirurhichnykh operatsii, zatverdzhenyi nakazom MOZ Ukrainy vid 14.02.2007 r. № 67).

8. Перспективи впровадження австралійської системи діагностично-споріднених груп в Україні (презентація, Кароліна Каланж, 8 березня 2019) https://wb.moz.gov.ua/en/struktura-proektu/komponent-3_-upravlinnia-proektom/ monitoryng-i-otsinka/novyny-ta-podii.html?action=view\&id=1483 (Perspektyvy vprovadzhennia avstraliiskoi systemy diahnostychno-sporidnenykh hrup v Ukraini (prezentatsiia, Karolina Kalanzh, 8 bereznia 2019 https://wb.moz.gov.ua/en/ struktura-proektu/komponent-3_-upravlinnia-proektom/monitoryng-i-otsinka/novyny-ta-podii.html?action=view\&id=1483). 
9. Що таке Австралійська система ДСГ та чому вона необхідна Україні? (презентація, В. Рудий, К. Россол, C. Дяченко, I. Могілевкіна, С. Сіромаха, М. Соколов, 23 січня 2018) https://wb.moz.gov.ua/struktura-proektu/ komponent-2_-tsentralni-komponenty/dsg/seminary-ta-robochi-narady.html?action=view\&id=167 (Shcho take Avstraliiska systema DSH ta chomu vona neobkhidna Ukraini? (prezentatsiia, V. Rudyi, K. Rossol, S. Diachenko, I. Mogilevkina, S. Siromakha, M. Sokolov, 23 sichnia 2018).

10. Australian Coding Standards. ACS. Tenth Edition, 1 July 2017. Independent Hospital Pricing Authority, 2017 (Австалійські страндарти кодування для МКХ-10-АМ та АКМІ. Десяте видання 1 липня 2017 р. НУКЦПМУ Незалежне управління по контролю цінової політики медичних установ https://academy.nszu.gov.ua/) (Avstaliiski strandarty koduvannia dlia MKKh-10-AM ta AKMI. Desiate vydannia 1 lypnia 2017 r. NUKTsPMU Nezalezhne upravlinnia po kontroliu tsinovoi polityky medychnykh ustanov https://academy.nszu.gov.ua/).

Дата надходження рукопису до редакції: 03.07.2020 p.

Мета - проаналізувати відмінності нового класифікатора хвороб та споріднених проблем охорони здоров'я від існуючого в Україні класифікатора, помилки при групуванні пролікованих випадків, розробити кроки щодо виправлення найчастіших помилок.

Матеріали та методи. Міжнародний статистичний класифікатор хвороб та споріднених проблем охорони здоров’я Десятого перегляду, Австралійської модифікації та НК 025:2019 - Класифікатора хвороб та споріднених проблем охорони здоров'я.

77603 випадки стаціонарного лікування, що внесені в електронну систему УДСГ протягом липня-листопада 2019 року в 14 пілотних лікарнях України в межах Проекту.

Результати. МКХ-10-АМ грунтується на МКХ-10, ВООЗ, тобто на класифікації, яка нам добре знайома, і яка використовувалась протягом багатьох років в Україні. Протягом перших 5 місяців кодування загалом 13,6\% випадків не були класифіковані у ДСГ. В 95\% випадків помилкового кодування епізод не відповідав критеріям жодної ДСГ, тобто основий діагноз не належав до жодної ДСГ або не міг бути віднесений до ДСГ за допомогою алгоритму.

Висновки. Відмінності запропонованого класифікатора хвороб та споріднених проблем охорони здоров'я МКХ-10-АМ не є критичними та не будуть перешкодою його впровадженню.

При впровадженні класифікатора МКХ-10-АМ в країні додатково необхідно зосередитись на алгоритмі пошуку потрібних кодів. У жодному випадку під час кодування не можна обмежуватись запропонованим в країні варіантом класифікатора НК 025:2019. Перекладений класифікатор МКХ-10-АМ в повному обсязі має бути доступними для фахівців, задіяних у процесі кодування.

Ключові слова: класифікатори австралійської системи ДСГ, впровадження в Україні, помилки при групуванні випадків.

Цель - проанализировать различия нового классификатора болезней и проблем здоровья от существующего в Украине классификатора, ошибки при группировке пролеченных случаев, разработать шаги по исправлению наиболее частых ошибок.

Материалы и методы. Международный статистический классификатор болезней и других проблем со здоровьем Десятого пересмотра, Австралийской модификации и НК 025: 2019 - Классификатор болезней и других проблем со здоровьем.

77603 случая стационарного лечения, внесенные в электронную систему УДСГ в течение июля-ноября 2019 году в 14 пилотных больницах Украины в рамках Проекта.

Результаты. МКБ-10-АМ базируется на МКБ-10 ВОЗ, то есть на классификации с которой мы хорошо знакомы, и которая использовалась в течение многих лет в Украине.

В течение первых 5 месяцев кодирования в целом 13,6\% случаев не были классифицированы к в диагностическиродственные группы (ДРГ). В 95\% случаев ошибочного кодирования эпизод не отвечал критериям ДРГ, то есть основной диагноз не принадлежал ни к одной ДРГ или не мог быть отнесен к ДРГ с помощью алгоритма.

Выводы. Отличия предложенного классификатора болезней и проблем здравоохранения МКБ-10-АМ не являются критическими и не будут помехой его внедрения.

При внедрении классификатора МКБ-10-АМ в стране дополнительно нужно сосредоточиться на алгоритме поиска необходимых кодов. Ни в коем случае при кодировании нельзя ограничиваться предложенным в стране классификатору НК 025:2019. Переведенный классификатор МКБ-10-АМ в полном объеме должен быть доступным для специалистов, задействованных в процессе кодирования.

Ключевые слова: классификаторы австралийской системы ДРГ, внедрение в Украине, ошибки при группировке случаев.

The purpose - to analyze the differences between the new classifier of diseases and related health problems from the existing one in Ukraine, errors in the grouping of inpatient cases, to develop steps to correct the most common errors. 
Materials and methods. International Statistical Classification of Diseases and Related Health Problems of the Tenth Revision, Australian Modification and NC 025:2019 - Classifier of Diseases and Related Health Problems.

77603 cases of inpatient treatment entered into the electronic UDRG system during July-November 2019 at 14 pilot hospitals in Ukraine within the Project.

Results. ICD-10-AM is based on ICD-10, WHO, ie a classification we are well familiar with, and has been used for many years in Ukraine.

During the first 5 months of coding, a total of $13.6 \%$ of cases were not classified for DRG. In $95 \%$ of cases of erroneous coding, the episode did not meet the criteria of any DRG, ie the basic diagnosis did not belong to any DRG or could not be attributed to DRG by the algorithm.

Conclusions. The differences of the proposed classifier of diseases and related health problems ICD-10-AM are not critical and will not be an obstacle to its implementation.

When implementing the ICD-10-AM classifier in the country, it is necessary to additionally be focused on the algorithm for required codes searching. In no case, when coding, one should be limited to the NC 025:2019 version of the classifier proposed in the country. The translated full version of the classifier ICD-10-AM should be available to professionals involved in the coding process.

Key words: Classifiers of Australian DRG system, implementation in Ukraine, errors in cases grouping.

Конфлікт інтересів: відсутній.

Conflicts of interest: authors have no conflicts of interest to declare.

Примітка: всі автори публікації до 30.06 .2020 р. були консультантами проекту «Пілотне впровадження системи ДСГ (на основі австралійської системи ДСГ) на рівні МО3 та вибраних медичних закладів (навчання, програмне забезпечення тощо)». Представлене дослідження виходить за межі проектного договору.

\section{Відомості про авторів}

Могілевкіна Ірина Олександрівна - д.мед.наук, професор, професор ННЦ НПО ІПО Національний медичний університет ім.О.О. Богомольця; 03057 м. Київ, просп. Перемоги, 34.

+380 (50) 473-90-59, imogilevkina@gmail.com, ORCID ID 0000-0001-8426-3841.

Дорохіна Анна Миколаївна - к.мед.наук, заступник головного лікаря по медичній частині ДУ «ННЦ «Інститут кардіології ім. акад. М.Д. Стражеска» НАМН України; 03680 м. Київ, вул. Народного Ополчення, 5.

+380 (97) 460-50-59, annadoroxina@ukr.net, ORCID ID 0000-0002-6853-8662.

Сіромаха Сергій Олегович - к.мед.наук, головний лікар ДУ «Національний інститут серцево-судинної хірургії ім. М.М. Амосова НАМН України»; 03038 м. Київ, вул. Амосова, 6. Національний медичний університет ім. О.О. Богомольця.

+380 (67) 997-30-25, newsersir@gmail.com, ORCID ID 0000-0002-7031-5732. 